\title{
Circulating Oxidized Low-Density Lipoproteins are Associated with Overweight, Obesity, and Low Serum Carotenoids in Older Community-Dwelling Women
}

\author{
Justine Beck ${ }^{\mathrm{a}}$, Luigi Ferrucci ${ }^{\mathrm{b}}$, Kai Sun ${ }^{\mathrm{a}}$, Linda P. Fried ${ }^{\mathrm{a}}$, Ravi Varadhan ${ }^{\mathrm{a}}$, Jeremy \\ Walston $^{\mathrm{a}}$, Jack M. Guralnik ${ }^{\mathrm{C}}$, and Richard D. Semba ${ }^{\mathrm{a}}$ \\ $\mathrm{a}_{\text {Johns Hopkins Medical Institutions Baltimore, Maryland }} \mathrm{b}_{\text {Longitudinal Studies Section, Clinical Research }}$ \\ Branch, National Institute on Aging, Baltimore, Maryland ${ }^{\mathrm{C}}$ Epidemiology, Demography and Biometry \\ Branch, National Institute on Aging, Bethesda, Maryland.
}

\begin{abstract}
Objective-The objective of this study was to determine whether total serum carotenoids, alphatocopherol, selenium, and obesity were independently associated with oxidized low-density lipoproteins (ox-LDL) in moderately to severe disabled older women living in the community.

Methods-Serum ox-LDL, carotenoids, alpha-tocopherol, and selenium were measured in a population-based sample of 543 moderately to severely disabled women, aged 65 and older, in the Women's Health and Aging Study I in Baltimore, Maryland.

Results—Total serum carotenoids, smoking, overweight (BMI $25-29.9 \mathrm{~kg} / \mathrm{m}^{2}$ ), and obesity $\left(\mathrm{BMI} \geq 30 \mathrm{mg} / \mathrm{kg}^{2}\right)$ were significantly associated with ox-LDL/LDL-cholesterol ratio after adjusting for age, C-reactive protein, and chronic diseases. Alpha-tocopherol and selenium were not significantly associated with ox-LDL/LDL-cholesterol ratio.
\end{abstract}

Conclusions-Older women who are overweight or obese or who have low total serum carotenoids are more likely to have higher lipoprotein oxidation. Weight reduction in overweight/obese women and increased intake of carotenoid-rich foods may potentially reduce lipoprotein oxidation.

\section{Keywords}

body mass index; carotenoids; low-density lipoproteins; obesity; oxidative stress

Oxidation of low-density lipoproteins is considered a key factor in the pathogenesis of atherosclerosis and cardiovascular disease [1]. Oxidized low-density lipoproteins (ox-LDL) are taken up by scavenger receptors on macrophages and contribute to the formation of foam cells and atherosclerotic lesions [1]. Elevated circulating ox-LDL are associated with more severe atherosclerotic lesions [2], and high circulating levels of ox-LDL have been shown to be independently predictive of subclinical atherosclerosis [3] and acute coronary heart disease [4].

Obesity is a strong risk factor for cardiovascular disease [5]. Both abdominal obesity and general obesity (body mass index $>30 \mathrm{~kg} / \mathrm{m}^{2}$ ) were shown to be independently associated with circulating ox-LDL among men and women, aged 25-74, in Spain [6]. Among subjects with

Correspondence to: Dr. Richard Semba, 550 N. Broadway, Suite 700, Baltimore, MD 21205. Tel. (410) 955-3572, Fax (410) 955-0629, email: rdsemba@jhmi.edu. 
and without coronary artery disease, body mass index was associated with circulating oxidized LDL [7]. Obese adults have higher systemic oxidative stress, as reflected by increased lipid peroxidation [8].

LDL is a large particle that contains one apoB molecule and a large number of triacylglycerol, free cholesterol, cholesterol ester, and phospholipid molecules [9]. LDL contains carotenes and xanthophylls, the two major classes of carotenoids in humans, and carotenoids protect LDL against oxidation [10]. The carotenoid content of LDL has been shown to be strongly correlated with serum carotenoid concentrations [11,12].

Although carotenoids are known to protect LDL particles from oxidation, the relationship between total serum carotenoid concentrations and circulating ox-LDL has not been well characterized in humans. We hypothesized that both obesity and low total serum carotenoids were associated with elevated circulating ox-LDL in older adults. To address this hypothesis, we assessed serum ox-LDL among older women living in the community who participated in the Women's Health and Aging Study I.

\section{Subjects and Methods}

Subjects in this study were women, aged 65 and older, who participated in the Women's Health and Aging Study I (WHAS I), a population-based study designed to evaluate the causes and course of physical disability in disabled older women living in the community. WHAS I participants were recruited from an age-stratified random sample of women aged 65 years and older selected from Medicare enrollees residing in 12 contiguous zip code areas in Baltimore [13]. Women were screened to identify self-reported moderate or severe physical disability based on categorization into four domains. The domains of disability were ascertained in a 20-30 minute home interview that included questions related to (1) mobility and exercise tolerance, i.e., walking for a quarter of a mile, walking up 10 steps without resting, getting in and out of bed or chairs, (2) upper extremity function, i.e., raising your arms up over your head, using your fingers to grasp or handle, lifting or carrying something as heavy as ten pounds, (3) higher functioning tasks (a subset of instrumental activities of daily living, not including heavy housework, i.e., using the telephone, doing light housework, preparing your own meals, shopping for personal items), and (4) basic self-care tasks (a subset of non-mobility dependent activities of daily living, i.e., bathing or showering, dressing, eating, using the toilet). WHAS I enrolled the one-third most disabled women ages 65 and older, those with disability in two or more domains. Of the 1409 women who met study eligibility criteria, 1002 agreed to participate in the study in 1992. There were no major differences in sociodemographic or reported health characteristics between eligible participants and those who declined to participate [13].

Standardized questionnaires were administered in the participant's home by trained interviewers. Mini-Mental Status Examination (MMSE) was recorded [13]. Race was assessed in a questionnaire as black, white, or other, current smoking as yes or no, and education as $0-8$, 9-11, 12 years, or more than 12 years. Two weeks later, a trained, registered full-time study nurse conducted an examination of each study participant in her home, using a standardized protocol that included physical performance measures and a standardized physical examination. Approximately $75 \%$ of women also consented to phlebotomy performed during a separate visit by a trained phlebotomist who followed a standardized protocol. Further details on the methods and sampling design of the WHAS studies are published elsewhere [13]. Demographic characteristics, self-rated health, and information about appetite and eating were measured in the WHAS questionnaires. Chronic diseases were adjudicated by WHAS coinvestigators based on the questionnaire, physical examination and physician contact [13]. 
There were 1002 women enrolled in the Women's Health and Aging Study I, of whom 753 women participated in the blood drawing at baseline. Eight hundred seventy-nine women returned for the 12-month follow-up visit, of whom 580 participated in the blood drawing. Analyses of serum ox-LDL, carotenoids, alpha-tocopherol, and selenium were conducted at the 12-month follow-up visit on 543 women.

Non-fasting blood samples were obtained by venipuncture between 9 AM and 2 PM. Processing, aliquoting, and freezing were carried out at the Core Genetics Laboratory of The Johns Hopkins University School of Medicine following a standardized protocol. Blood samples were delivered to Quest Diagnostics Laboratories (Teterboro, New Jersey) and other aliquots were stored continuously at $-70^{\circ} \mathrm{C}$ until the time of laboratory analyses. Total cholesterol and HDL cholesterol were measured by enzymatic methods at Quest Diagnostics. LDL cholesterol was calculated using the Friedewald equation [14].

Serum ox-LDL were measured using enzyme-linked immunosorbent assay (Mercodia Oxidized LDL ELISA, Uppsala, Sweden). The inter-assay coefficient of variation (CV) was $12 \%$. Serum carotenoids and alpha-tocopherol were measured by high performance liquid chromatography (HPLC) [15]. Total carotenoids were calculated as the sum of $\alpha$-carotene, $\beta$ carotene, $\beta$-cryptoxanthin, lutein/zeaxanthin, and lycopene in $\mu \mathrm{mol} / \mathrm{L}$. The inter-assay $\mathrm{CVs}$ for $\alpha$-carotene, $\beta$-carotene, $\beta$-cryptoxanthin, lutein, zeaxanthin, lycopene, and $\alpha$-tocopherol were $12 \%, 8 \%, 4 \%, 12 \%, 12 \%, 7 \%$, and $11 \%$, respectively. Plasma selenium was measured by graphite furnace atomic absorption spectrometry using a Perkin Elmer AAnalyst 600 with Zeeman background correction. Samples were diluted 1:4 with a triton-X (Sigma Chemical, St. Louis, MO) and nitric acid solution (Fisher Scientific, Pittsburgh, PA), and the matrix modifier was a palladium and magnesium nitrate solution (both Perkin Elmer, Norwalk, CT). The instrument was calibrated daily using known plasma selenium standards (UTAK Laboratories, Inc., Valencia, CA). The inter-assay CV for selenium was $2 \%$.

Oxidized LDL concentrations are strongly correlated with that of its substrate LDL-cholesterol, and the ratio of ox-LDL to LDL-cholesterol was used in the analyses [16,17]. The results of the Mercodia ELISA for ox-LDL are expressed in U/L, thus, the ratio of ox-LDL to LDLcholesterol is given as ox-LDL (U/L) divided by LDL-cholesterol $(\mathrm{mg} / \mathrm{dL})$. Body mass index was categorized as underweight $\left(<18.5 \mathrm{~kg} / \mathrm{m}^{2}\right)$, normal range $\left(18.5-24.9 \mathrm{~kg} / \mathrm{m}^{2}\right)$, overweight $\left(\geq 25-29.9 \mathrm{~kg} / \mathrm{m}^{2}\right)$, and obese $\left(\geq 30 \mathrm{~kg} / \mathrm{m}^{2}\right)$ according to World Health Organization criteria [18]. Univariate and multivariate linear regression models were used to examine the relationship of demographic, nutritional, inflammatory measures, and chronic diseases with the ox-LDL/LDL-cholesterol ratio. Variables that were associated with ox-LDL/LDLcholesterol ratio in univariate models $(P<0.10)$ were entered into a final multivariate linear regression model with ox-LDL/LDL-cholesterol ratio as the dependent variable. The statistical program used was SAS Version 9.13 (SAS Institute, Cary, NC).

\section{Results}

Demographic characteristics, body mass index, mean serum ox-LDL, total carotenoids, alphatocopherol, selenium, and C-reactive protein concentrations, and chronic diseases of the 543 women at 12 months follow-up visit are shown in Table 1 . The univariate relationships between these factors and ox-LDL/LDL-cholesterol ratio are shown in linear regression models in Table 2. Overweight, obesity, total serum carotenoids, C-reactive protein, cancer, and renal disease were significantly associated with ox-LDL/LDL-cholesterol ratio, and current smoking and coronary heart disease were marginally associated (both $P=0.06$ ) with ox-LDL/LDLcholesterol ratio. Age, race, education, serum selenium, hypertension, peripheral artery disease, stroke, diabetes mellitus, and chronic obstructive lung disease were not associated with oxLDL/LDL-cholesterol ratio. 
As a previous study has shown a relationship between BMI and ox-LDL [7], we examined the relationship between BMI $\left(\mathrm{kg} / \mathrm{m}^{2}\right)$ and ox-LDL in separate linear regression models. BMI (per $1 \mathrm{~kg} / \mathrm{m}^{2}$ ) was associated with ox-LDL in models adjusting for age (beta $=0.42, \mathrm{SE}=0.12, P$ $=0.001$ ), and adjusting for age, current smoking, serum carotenoids, $C$-reactive protein coronary artery disease, cancer, and renal disease (beta $=0.44, \mathrm{SE}=13, P=0.001$ ).

In a final multivariate linear regression model, current smoking, overweight, obesity, total serum carotenoids, cancer, and chronic renal disease were associated with ox-LDL/LDLcholesterol ratio (Table 3$)$. Coronary artery disease was marginally $(P=0.06)$ associated with ox-LDL/LDL-cholesterol ratio in the final model.

\section{Discussion}

This study shows that, among moderately to severely disabled older women living in the community, overweight, obesity and low total serum carotenoids are independently associated with elevated circulating ox-LDL/LDL-cholesterol ratio, adjusting for co-existing diseases. To our knowledge, this is the first study to show that low total serum carotenoids are associated with elevated circulating ox-LDL in humans. Higher total plasma carotenoid concentrations have been associated with greater oxidative stability of LDL [19]. While causality cannot be inferred here, this study's finding of an association between total carotenoids and ox-LDL is consistent with growing number of studies showing that increased intake or dietary supplementation with carotenoid-rich foods increases the oxidative stability of LDL [20-24]. Serum carotenoid levels are a strong indicator of fruit and vegetable intake. Other antioxidants in fruits and vegetables such as ascorbate, flavonoids and other plant polyphenols that were not measured in the study could potentially play a role in oxidation of LDLs.

This study corroborates previous investigations that show an association between obesity and elevated circulating ox-LDL concentrations [6,7]. Abdominal obesity was independently associated with ox-LDL [6,25], providing a link between ox-LDL and the metabolic syndrome [26]. A limitation of the present study is that waist circumference was not measured. In a twelve week clinical intervention study, weight loss was accompanied by a decrease in circulating oxLDL concentrations among obese women [27]. In another study, exercise and diet-induced weight loss decreased circulating ox-LDL concentrations in adults with the metabolic syndrome [28].

Cigarette smoke is well known to increase oxidative stress [29], which is consistent with the finding of an association between current smoking and higher ox-LDL/LDL-cholesterol ratio in the present study. Coronary heart disease was also associated with a higher ox-LDL/LDLcholesterol ratio, which is consistent with previous studies [2-4]. Women with cancer also had a higher ox-LDL/LDL-cholesterol ratio than women without cancer in this study, which is consistent with a previous study that showed elevated ox-LDL in women with breast or ovarian cancer [30].

A healthy food pattern, such as the Mediterranean style diet, has been associated with decreased oxidizability of LDL particles [31-34], reduced inflammation [35-37], reduced risk of cardiovascular disease [31], and lower mortality [38]. Dietary factors have been shown to modulate ox-LDL, but inconsistent results have been shown for antioxidant supplements and ox-LDL [33]. For example, studies have failed to show any effect of beta-carotene supplementation on susceptibility of LDL particles to oxidation [33]. However, intervention studies have utilized mega-doses of beta-carotene $(30-60 \mathrm{mg} / \mathrm{day}][39,40]$. Mega-dose supplementation with beta-carotene at a high level is not physiological and has actually been shown to increase oxidative stress [41]. A healthy dietary pattern such as adoption of a 
Mediterranean style diet appears to be the most promising approach to reduce levels of oxLDL [33].

\section{Conclusions}

Among moderately to severely disabled older women living in the community, low serum carotenoids, overweight, and obesity were associated with higher ox-LDL, a key factor involved in the pathogenesis of atherosclerosis and cardiovascular disease. Weight reduction in overweight/obese women and increased intake of carotenoid-rich foods, i.e., fruits and vegetables, may be potential strategies to reduce ox-LDL.

\section{Acknowledgements}

This work was supported by National Institute on Aging Grant R01 AG027012, AG11703-01A1, NIH-NCRR, OPDGCRC grant RR00722, R01 AI41956, NIA Contract N01-AG12112, and the Intramural Research Program, National Institute on Aging, NIH.

\section{References}

1. Hansson GK. Inflammation, atherosclerosis, and coronary artery disease. N Engl J Med 2005;352:1685-95. [PubMed: 15843671]

2. Yamashita H, Ehara S, Yoshiyama M, Naruko T, Haze K, Shirai N, Sugama Y, Ikura Y, Ohsawa M, Itabe H, Kataoka T, Kobayashi Y, Becker AE, Yoshikawa J, Ueda M. Elevated plasma levels of oxidized low-density lipoprotein relate to the presence of angiographically detected complex and thrombotic coronary artery lesion morphology in patients with unstable angina. Circ J 2007;71:6817. [PubMed: 17456991]

3. Hulthe J, Fagerberg B. Circulating oxidized LDL is associated with subclinical atherosclerosis development and inflammatory cytokines (AIR Study). Arterioscler Thromb Vasc Biol 2002;22:11627. [PubMed: 12117732]2002

4. Meisinger C, Baumert J, Khuseyinova N, Loewel H, Koenig W. Plasma oxidized low-density lipoprotein, a strong predictor for acute coronary heart disease events in apparently healthy, middleaged men from the general population. Circulation 2005;112:651-7. [PubMed: 16043640]

5. Poirier P, Giles TD, Bray GA, Hong Y, Stern JS, Pi-Sunyer FX, Eckel RH. Obesity and cardiovascular disease: pathophysiology, evaluation, and effect of weight loss: an update of the 1997 American Heart Association Scientific Statement on Obesity and Heart Disease from the Obesity Committee of the Council on Nutrition, Physical Activity, and Metabolism. Circulation 2006;113:898-918. [PubMed: 16380542]

6. Weinbrenner T, Schröder H, Escurriol V, Fito M, Elosua R, Vila J, Marrugat J, Covas MI. Circulating oxidized LDL is associated with increased waist circumference independent of body mass index in men and women. Am J Clin Nutr 2006;83:30-5. [PubMed: 16400046]

7. Holvoet P, Mertens A, Verhamme P, Bogaerts K, Beyens G, Verhaeghe R, Collen D, Muls E, van de Werf F. Circulating oxidized LDL is a useful marker for identifying patients with coronary artery disease. Arterioscler Thromb Vasc Biol 2001;21:844-8. [PubMed: 11348884]

8. Keaney JF Jr, Larson MG, Vasan RS, Wilson PWF, Lipinska I, Corey D, Massaro JM, Sutherland P, Vita JA, Benjamin EJ. Obesity and systemic oxidative stress: clinical correlates of oxidative stress in the Framingham Study. Arterioscler Thromb Vasc Biol 2003;23:434-9. [PubMed: 12615693]

9. Itabe H, Ueda M. Measurement of plasma oxidized low-density lipoprotein and its clinical implications. J Atheroscler Thromb 2007;14:1-11. [PubMed: 17332686]

10. McEligot AJ, Yang S, Meyskens FL Jr. Redox regulation by intrinsic species and extrinsic nutrients in normal and cancer cells. Annu Rev Nutr 2005;25:261-95. [PubMed: 16011468]

11. Ziouzenkova O, Winklhofer-Roob BM, Puhl H, Roob JM, Esterbauer H. Lack of correlation between alpha-tocopherol content of plasma and LDL, but high correlations for gamma-tocopherol and carotenoids. J Lipid Res 1996;37:1936-46. [PubMed: 8895059]

12. Perugini C, Bagnati M, Cau C, Bordone R, Zoppis E, Paffoni P, Re R, Albano E, Bellomo G. Distribution of lipid-soluble antioxidants in lipoproteins from healthy subjects. I. Correlation with 
plasma antioxidant levels and composition of lipoproteins. Pharmacol Res 2000;41:55-65. [PubMed: 10600270]

13. Guralnik, JM.; Fried, LP.; Simonsick, EM.; Kasper, D.; Lafferty, ME. The Women's Health and Aging Study: Health and Social Characteristics of Older Women with Disability. National Institute on Aging; Bethesda, MD: 1995. NIH Publication No. 95-4009

14. Friedewald WT, Levy RI, Frederikson DS. Estimation of the concentration of low-density- lipoprotein cholesterol in plasma, without use of the preparative ultracentrifuge. Clin Chem 1972;18:499-502. [PubMed: 4337382]

15. Lauretani F, Semba RD, Bandinelli S, Dayhoff-Brannigan M, Guralnik JM, Ferrucci L. Older community-dwelling adults with low plasma carotenoids show a greater decline in skeletal muscle strength over six years. J Gerontol A Biol Sci Med Sci. In press

16. Holvoet P, Harris TB, Tracy RP, Verhamme P, Newman AB, Rubin SM, Simonsick EM, Colbert LH, Kritchvsky SB. Association of high coronary heart disease risk status with circulating oxidized LDL in the well-functioning elderly: findings from the Health, Aging, and Body Composition Study. Arterioscler Thromb Vasc Biol 2003;23:1444-8. [PubMed: 12791672]

17. Cesari M, Kritchevsky SB, Nicklas BJ, Penninx BWHJ, Holvoet P, Koh-Banerjee P, Cummings SR, Harris TB, Newman AB, Pahor M. Lipoprotein peroxidation and mobility limitation: results from the Health, Aging, and Body Composition Study. Arch Intern Med 2005;165:2148-54. [PubMed: 16217006]

18. James PT, Leach R, Kalamara E, Shayeghi M. The worldwide obesity epidemic. Obes Res 2001;9 (suppl 4):228S-33S. [PubMed: 11707546]

19. Lowe GM, Bilton RF, Davies IG, Ford TC, Billington D, Young AJ. Carotenoid composition and antioxidant potential in subfractions of human low-density lipoprotein. Ann Clin Biochem 1999;36:323-32. [PubMed: 10376074]

20. Agarwal S, Rao AV. Tomato lycopene and low density lipoprotein oxidation: a human dietary intervention study. Lipids 1998;33:981-4. [PubMed: 9832077]

21. Chopra M, O’Neill ME, Keogh N, Wortley G, Southon S, Thurnham DI. Influence of increased fruit and vegetable intake on plasma and lipoprotein carotenoids and LDL oxidation in smokers and nonsmokers. Clin Chem 2000;46:1818-29. [PubMed: 11067818]

22. Upritchard JE, Sutherland WH, Mann JI. Effect of supplementation with tomato juice, vitamin E, and vitamin $\mathrm{C}$ on LDL oxidation and products of inflammatory activity in type 2 diabetes. Diabetes Care 2000;23:733-8. [PubMed: 10840987]

23. Kiokas S, Gordon MH. Dietary supplementation with a natural carotenoid mixture decreases oxidative stress. Eur J Clin Nutr 2003;59:1135-40.

24. Visioli F, Riso P, Grande S, Galli C, Porrini M. Protective activity of tomato products on in vivo markers of lipid oxidation. Eur J Nutr 2003;42:201-6. [PubMed: 12923651]

25. Couillard C, Ruel G, Archer WR, Pomerleau S, Bergeron J, Couture P, Lamarche B, Bergeron N. Circulating levels of oxidative stress markers and endothelial adhesion molecules in men with abdominal obesity. J Clin Endocrinol Metab 2005;90:6454-9. [PubMed: 16189262]

26. Knopp RH, Paramsothy P. Oxidized LDL and abdominal obesity: a key to understanding the metabolic syndrome. Am J Clin Nutr 2006;83:1-2. [PubMed: 16400040]

27. Shin MJ, Hyun YJ, Kim OY, Kim JY, Jang Y, Lee JH. Weight loss effect on inflammation and LDL oxidation in metabolically healthy by obese (MHO) individuals: low inflammation and LDL oxidation in MHO women. Int J Obesity 2006;30:1529-34.

28. Rector RS, Warmer SO, Liu Y, Hinton PS, Sun GY, Cox RH, Stump CS, Laughlin MH, Dellsperger $\mathrm{KC}$, Thomas TR. Exercise and diet induced weight loss improves measures of oxidative stress and insulin sensitivity in adults with characteristics of the metabolic syndrome. Am J Physiol Endocrinol Metab 2007;293:E500-6. [PubMed: 17473052]

29. Yanbaeva DG, Dentener MA, Creutzberg EC, Wesseling G, Wouters EF. Systemic effects of smoking. Chest 2007;131:1557-66. [PubMed: 17494805]

30. Delimaris I, Faviou E, Antonakos G, Stathopoulou E, Zachari A, Dionyssiou-Asteriou A. Oxidized LDL, serum oxidizability and serum lipid levels in patients with breast or ovarian cancer. Clin Biochem 2007;40:1129-34. [PubMed: 17673194]2007 
31. Pangiotakos DB, Pitsavos C, Chrysohoou C, et al. Status and management of blood lipids in Greek adults and their relation to socio-demographic, lifestyle and dietary factors: the ATTICA Study. Blood lipids distribution in Greece. Atherosclerosis 2004;173:353-61. [PubMed: 15064113]

32. Lapointe A, Goulet J, Couillard C, Lamarche B, Lemieux S. A nutritional intervention promoting the Mediterranean food pattern is associated with a decrease in circulating oxidized LDL particles in healthy women from the Quebec City metropolitan area. J Nutr 2005;135:410-5. [PubMed: 15735071]

33. Lapointe A, Couillard C, Lemieux S. Effects of dietary factors on oxidation of low-density lipoprotein particles. J Nutr Biochem 2006;17:645-58. [PubMed: 16517144]

34. Fitó M, Guxens M, Corella D, Sáez G, Estruch R, de la Torre R, Francés F, Cabezas C, LópezSabaterMdel C, Marrugat J, García-Arellano A, Aórs F, Ruiz-Gutierrez V, Ros E, Salas-Salvadó J, Fiol M, Solá R, Covas MI. Effect of a traditional Mediterranean diet on lipoprotein oxidation: a randomized controlled trial. Arch Intern Med 2007;167:1195-203. [PubMed: 17563030]

35. Chrysohoou C, Panagiotakos DB, Pitsavos C, Das UN, Stefanadis C. Adherence to the Mediterranean diet attenuates inflammation and coagulation process in health adults: the ATTICA Study. J Am Coll Cardiol 2004;44:152-8. [PubMed: 15234425]

36. Esposito K, Marfella R, Ciotola M, Di Palo C, Giugliano F, Giugliano G, D’Armiento M, D’ Andrea F, Giugliano D. Effect of a Mediterranean-style diet on endothelial dysfunction and markers of vascular inflammation in the metabolic syndrome: a randomized trial. JAMA 2004;292:1440-6. [PubMed: 15383514]

37. Estruch R, Martínez-González MA, Corella D, Salas-Salvadó, Ruiz-Gutiérrez V, Covas MI, Fiol M, Gómez-Garcia E, López-Sabater MC, Vinyoles E, Arós F, Conde M, Lahoz C, Lapetra J, Sáenz G, Ros E. Effects of a Mediterranean-style diet on cardiovascular risk factors: a randomized trial. Ann Intern Med 2006;145:1-11. [PubMed: 16818923]

38. Trichopoulou A, Costacou T, Bamia C, Trichopoulos D. Adherence to a Mediterranean diet and survival in a Greek population. N Engl J Med 2003;348:2599-608. [PubMed: 12826634]

39. Reaven PD, Khouw A, Beltz WF, Parthasarathy S, Witztum JL. Effect of dietary antioxidant combinations in humans. Protection of LDL by vitamin E but not by beta-carotene. Arterioscler Thromb 1993;13:590-600. [PubMed: 8466894]

40. Meraji S, Ziouzenkova O, Resch U, Khoschsorur A, Tatzber F, Esterbauer H. Enhanced plasma level of lipid peroxidation in Iranians could be improved by antioxidants supplementation. Eur J Clin Nutr 1997;51:318-25. [PubMed: 9152683]

41. Palozza, P.; Krinsky, NI. Evidence for pro-oxidant effects of carotenoids in vitro and in vivo: implications in health and disease. In: Mayne, ST.; Sies, H., editors. Carotenoids in Health and Disease. Marcel Dekker; New York: 2004. p. 127-49. 
Table 1

Characteristics of older women living in the community in the Women's Health and Aging Study I at the 12 month follow-up visit

\begin{tabular}{|c|c|c|c|c|}
\hline \multicolumn{2}{|l|}{ Characteristic } & $N$ & Mean or $\%$ & SD \\
\hline \multicolumn{2}{|l|}{ Age (y) } & 554 & 77.9 & 7.7 \\
\hline \multicolumn{2}{|l|}{ White (\%) } & 392 & 70.7 & --- \\
\hline \multicolumn{2}{|l|}{ Education $<12$ years $(\%)$} & 344 & 62.3 & --- \\
\hline \multicolumn{2}{|l|}{ Current smoker $(\%)$} & 60 & 10.8 & --- \\
\hline \multirow[t]{4}{*}{ Body mass index $\left(\mathrm{kg} / \mathrm{m}^{2}\right)(\%)$} & $<18.5$ & 16 & 3.2 & -- \\
\hline & $18.5-24.9$ & 123 & 24.5 & --- \\
\hline & 25.0-29.9 & 175 & 34.8 & --- \\
\hline & $\geq 30$ & 188 & 37.5 & --- \\
\hline \multicolumn{2}{|l|}{ Total cholesterol $(\mathrm{mg} / \mathrm{dL})$} & 543 & 226 & 45 \\
\hline \multicolumn{2}{|l|}{ LDL-cholesterol (mg/dL) } & 542 & 141 & 42 \\
\hline \multicolumn{2}{|l|}{ HDL-cholesterol (mg/dL) } & 542 & 52 & 16 \\
\hline \multicolumn{2}{|l|}{ Triglycerides $(\mathrm{mg} / \mathrm{dL})$} & 543 & 163 & 100 \\
\hline \multicolumn{2}{|l|}{ Ox-LDL (U/L) } & 554 & 89.7 & 28.4 \\
\hline \multicolumn{2}{|c|}{ Total serum carotenoids $(\mu \mathrm{mol} / \mathrm{L})$} & 554 & 1.53 & 0.70 \\
\hline \multicolumn{2}{|l|}{ Serum alpha-tocopherol $(\mu \mathrm{mol} / \mathrm{L})$} & 554 & 36.7 & 14.2 \\
\hline \multicolumn{2}{|l|}{ Serum selenium $(\mu \mathrm{g} / \mathrm{L})$} & 552 & 115 & 22 \\
\hline \multicolumn{2}{|c|}{ Serum $\log _{\mathrm{e}} \mathrm{C}$-reactive protein $(\mathrm{mg} / \mathrm{L})$} & 533 & 1.48 & 0.84 \\
\hline \multicolumn{2}{|l|}{ Hypertension (\%) } & 325 & 58.8 & --- \\
\hline \multicolumn{2}{|l|}{ Coronary heart disease $(\%)$} & 125 & 22.6 & --- \\
\hline \multicolumn{2}{|l|}{ Peripheral artery disease $(\%)$} & 114 & 20.6 & --- \\
\hline \multicolumn{2}{|l|}{ Stroke $(\%)$} & 27 & 4.9 & --- \\
\hline \multicolumn{2}{|l|}{ Diabetes mellitus (\%) } & 84 & 15.2 & --- \\
\hline \multicolumn{2}{|c|}{ Chronic obstructive lung disease $(\%)$} & 156 & 28.2 & --- \\
\hline \multicolumn{2}{|l|}{ Depression $(\%)$} & 74 & 13.7 & --- \\
\hline \multicolumn{2}{|l|}{ Cancer $(\%)$} & 62 & 11.2 & --- \\
\hline \multicolumn{2}{|l|}{ Renal disease (\%) } & 52 & 9.6 & --- \\
\hline
\end{tabular}


Table 2

Univariate linear regression models of the relationship between oxidized low-density lipoprotein/LDLcholesterol ratio with demographic and nutritional factors and chronic diseases among older women living in the community

\begin{tabular}{|c|c|c|c|c|}
\hline \multicolumn{2}{|l|}{ Characteristic } & Beta & SE & $P$ \\
\hline \multicolumn{2}{|l|}{ Age (y) } & -0.002 & 0.001 & 0.24 \\
\hline \multicolumn{2}{|l|}{ White } & -0.023 & 0.023 & 0.33 \\
\hline \multicolumn{2}{|l|}{ Education $<12$ years } & -0.010 & 0.022 & 0.65 \\
\hline \multicolumn{2}{|l|}{ Current smoker } & 0.066 & 0.035 & 0.06 \\
\hline \multirow[t]{3}{*}{ Body mass index $\left(\mathrm{kg} / \mathrm{m}^{2}\right)$} & $<18.5$ & -0.027 & 0.065 & 0.67 \\
\hline & 25.0-29.9 & 0.067 & 0.027 & 0.01 \\
\hline & $\geq 30$ & 0.069 & 0.026 & 0.009 \\
\hline \multicolumn{2}{|c|}{ Total serum carotenoids $(\mu \mathrm{mol} / \mathrm{L})$} & -0.080 & 0.016 & $<0.0001$ \\
\hline \multicolumn{2}{|c|}{ Serum alpha-tocopherol $(\mu \mathrm{mol} / \mathrm{L})$} & 0.001 & 0.001 & 0.28 \\
\hline \multicolumn{2}{|l|}{ Serum selenium $(\mu \mathrm{g} / \mathrm{L})$} & -0.001 & 0.001 & 0.55 \\
\hline \multicolumn{2}{|c|}{ Serum $\log _{\mathrm{e}}$ C-reactive protein $(\mathrm{mg} / \mathrm{L})$} & 0.030 & 0.013 & 0.02 \\
\hline \multicolumn{2}{|l|}{ Hypertension } & -0.013 & 0.022 & 0.56 \\
\hline \multicolumn{2}{|l|}{ Coronary heart disease } & 0.047 & 0.026 & 0.06 \\
\hline \multicolumn{2}{|l|}{ Peripheral artery disease } & 0.037 & 0.027 & 0.16 \\
\hline \multicolumn{2}{|l|}{ Stroke } & -0.027 & 0.049 & 0.59 \\
\hline \multicolumn{2}{|l|}{ Diabetes mellitus } & 0.047 & 0.030 & 0.12 \\
\hline \multicolumn{2}{|c|}{ Chronic obstructive lung disease } & -0.017 & 0.024 & 0.49 \\
\hline \multicolumn{2}{|l|}{ Depression } & -0.009 & 0.033 & 0.78 \\
\hline \multicolumn{2}{|l|}{ Cancer } & 0.084 & 0.034 & 0.01 \\
\hline \multicolumn{2}{|l|}{ Renal disease } & -0.072 & 0.037 & 0.05 \\
\hline
\end{tabular}


Table 3

Multivariate linear regression model of the relationship between oxidized low-density lipoprotein/LDLcholesterol ratio with demographic and nutritional factors and chronic diseases among older women living in the community

\begin{tabular}{|l|r|r|r|r|}
\hline \multicolumn{2}{|l|}{ Characteristic } & Beta & SE & \multicolumn{1}{c|}{$\boldsymbol{P}$} \\
\hline \multicolumn{2}{|l|}{ Age $(\mathrm{y})$} & 0.001 & 0.001 & 0.92 \\
\hline \multicolumn{2}{|l|}{ Current smoker } & 0.073 & 0.039 & 0.06 \\
\hline \multirow{3}{*}{ Body mass index $\left(\mathrm{kg} / \mathrm{m}^{2}\right)$} & $25.0-29.9$ & 0.065 & 0.030 & 0.03 \\
\cline { 2 - 5 } & $\geq 30$ & 0.070 & 0.031 & 0.03 \\
\cline { 2 - 5 } & & -0.070 & 0.016 & $<0.0001$ \\
\hline Total serum carotenoids $(\mu \mathrm{mol} / \mathrm{L})$ & 0.011 & 0.013 & 0.42 \\
\hline Serum log $\mathrm{e}$ C-reactive protein $(\mathrm{mg} / \mathrm{L})$ & 0.048 & 0.027 & 0.07 \\
\hline Coronary artery disease & 0.103 & 0.035 & 0.003 \\
\hline Cancer & -0.067 & 0.039 & 0.08 \\
\hline Renal disease & & & \\
\hline
\end{tabular}

